\title{
Values of Islam as Religion: Challenges to Modernism for Present and Future
}

\author{
MD. Cholem Ullah \\ Assistant Professor in Islamic History and Culture \\ Centre for University Requirement Courses (CENURC) \\ International Islamic University Chittagong (IIUC) \\ Kumira, Sitakunda, Chittagong, Bangladesh. Post Code: 4318
}

\begin{abstract}
This article attempts to find out the challenges of Islam dealing modernism from the standpoint of religious faith and values. Actually, the concept of modernism and incredible growth of materialism symbolize the faith and religion merely unscientific inculcating such mysterious and uncertain matters. Islam's relationship as religion with the modernism, though it goes far into antiquity, has been overburdened with rivalries and marred by conflicts. But, certainly Islamic faith and other traditions are governed in the belief of oneness in God with being His all omnipotent and absolute powers that promulgate denoting challenges in the modern life of the world, particularly in the climax of modern scientific developments concerted by western world. The article also shed lights on the comprehensive analysis regarded the necessity of Islam with a view to reconstructing modernism as well as glorifying Islamic faith bearing out as only universal religious ideology in the world forever rather modernism or more than that.
\end{abstract}

DOI: $10.7176 / \mathrm{JPCR} / 51-04$

Publication date: January $31^{\text {st }} 2021$

\section{Introduction}

Today, many live in an era marked by an unparalleled advance of science. At the same time, man remains in a theological or religious crisis to preserve the social and cultural traditions of his current societies. The real fact is that the enormous advance of modern science on a scale hitherto and the emergence of modern materialistic are causing serious questioning of religious values and practices. The idea of the creator, the origin of the world, the creation of human beings and even God's nature have become susceptible to grave doubt and random speculation as a consequence of reality. Religion is now being criticized as a non-scientific and outdated concept that has little significance in the broader sense of modern life.(Ramadan, 2001)

The non-believers argue that the existence of God in purpose has not been proved or is demonstrable. The essence of posthumous life is equally mysterious and uncertain. In general, this new opposition of religion and the incredible growth of secular perspective are not isolated phenomena. Concerning the essence of man and the world, they reflected a profound shift of viewpoint and definition.

Religion and its faith are coherently related to the life of humanity. Man has lived according to faith and religious practice since the dawn of history, though faith is unnatural to man. There might have been many cases of abuse, superstitions, deviation and corruption in the religious life of man, nevertheless the primary religious faith remained unquestioned. God was still regarded as the absolute Lord and the creator of everything; the Devil was all evil. In the religious life of the world, there may have been many crimes, superstitions, deviations and corruption, but the fundamental religious faith remained unquestioned. Since God is always called the absolute Lord and maker of all; the Devil was all evil. All have been in its proper role and relationship, but the ongoing theological question is increasingly becoming global. Religion used to control life in the past. Still, now it is happening in one's world today is that secular outlook or modernism dominates life and pushes religion out of life, drives it through and even stifles it to the point of death in his/her private life.

It is possible to define modernism as that which is not of divine origin or that which does not come from faith or tradition. Many modern aspects have been accommodated by tradition and modernity has incorporated some of the values dear to Muslims. Tradition is in the process of transition, and modernity is not opposed to tradition being embraced. Evidently, in tradition, there is modernity and vice versa; they connect and influence one another.(Moten, 2011)

Modernism, in reality, is radically anti-religious, anti-traditional, human, science, progressive, etc. By expanding its hegemony over the rest of the world, such a modernist worldview has already achieved an overall ascendancy in the West and is now becoming universal. By hitting at their origin, this Modernism seeks to destroy faith and tradition. Indeed, it was the birthplace of the European Renaissance, marking the end of traditional Christian culture. The Renaissance began the process of an open rebellion against God. Eventually, it gave birth to several new dogmas and 'isms' such as secularism and Marxist communism, both of which constitute modernism.(Haq, 2008)

In truth, these 'isms' apparently appealing and persuasive, are aberrant, representing a stray into mistakes and 
delusions, embedded in the changing ground of speculation and superficial knowledge. Surprised by the unparalleled development of modern science, scientists appear to embrace only those things that are connected to time, space, matter, and senses as the true reality; they conclude that only the natural world, the world of phenomena, is real or genuine and that nothing exists beyond.(Haq, 2008) And it is the contemporary materialism, exclusively which is a theory of anti-wisdom due to its residing on the husk of objects, ignoring their divine nature and reality, and phenomena on the surface level. This is a brain superficiality that closes its eyes to what is the quintessence of the human experience.(Northbourne, 1963)

\section{Understanding Religion}

From such relation of modernism with present world phenomena, of course, religion is subjected to Modernism's challenges. Religion is like humanity itself, and originates fundamentally from the spiritual source. It symbolizes a series of divine instructions resealed to various prophets and messengers of Allah to direct humanity down the right direction. It aims to provide a successful link between a slave and his creator Allah. Hence, primacy and ultimacy of religion in human life are undeniable. Despite outward differences and apparent contradictions, all true and revealed religions provide paths or highways leading to the same goal. Every religion is like a highway, not an ism or ideology, and a highway exists in terms of its destination. There's simply no path that leads nowhere. It must have a starting point as well as a destination because religion is primarily a highway. As confidence flows from Heaven, so it ends in Heaven. Thus, God himself is the aim of religion.(Haq, 2008)

Religion has doctrinal, ritual, and ethical elements that are interlinked and inseparable. This means that religion is not a purely personal or private matter; it is a supara-individual instead. Each religion is distinguished by three factors - doctrine, ritual, and ethics - equate to three human faculties — intelligence, behavior, and option differentiate each faith.

This indicates that religion lacks and neglects human beings.(Northbourne, 1963) From birth to death, outward and inward, it includes the whole of life. Religion is extraneous to man in fact. In Islam, the nucleus or concentration of knowledge of religious consciousness or Spiritual Truth is referred to as al-fitrah (30:30) in alQur'an, that is, a primordial existence in man that represents his unique ability to accept God as his Lord.

Imam al-Ghazali's famous theosophy remarks that each person is born into his fitrah, that is, primordial existence, with the consciousness of Divine Unity, a conviction that is kneaded.(Al-ghazali, 1358/1937) The Latin origin of the word religion refers to the principle of attachment binding. Therefore, faith denotes a bond between humanity and what is more significant than itself, God. The same topic is represented in Islam with the word $a q l$, which means intellect. The root sense of the word ' $a q l^{\prime}$ ' is binding. Now, the human faculty that connects man to his God, to his origins, is intellect or 'aql'. That is why al-Qur'an frequently refers to men as having 'aql,' i.e. intelligence.(Nasr, 1979) This implies that all true religions have a fundamental unity. Religion can differ between human and times or and social law, but it is always the same in its essentials. In this context, a quotation from Schoun seems relevant: Just as every color, by its negation of darkness and its affirmation of light, offers the possibility of discovering the ray that makes it visible and of tracing that ray back to its luminous source, so all forms, all symbols, all religions, through their denial of error and their affirmation of truth, make it possible to trace the ray of revelation back to its Divine Source.(Frithjof Schuon, 1984) Al-Qur' an also affirms that fundamental beliefs of a religion are universally common to all peoples of Book (3:34). Al-Qur 'an also states that all peoples of the Book are uniformly common to fundamental beliefs of faith (3: 34). Hence, religion is the perennial tradition of humanity, since man has not existed without religion ever since the dawn of history. It was only in today's modern era, marked by the so-called civilized maturity of humanity, that man began to live without religion.

\section{Values of Islam as a Religion}

We now turn to the principles of Islam as a religion, from such general remarks regarding faith or religion. Islam is based primarily on the doctrine of Divine Unity which in Islamic terminology is called Tawhid. The fundamental and axial doctrine of Islam is always echoed in al-Qur'an to us; for everything in Islam either revolves around it or stems from it. It is not a theoretical concept or a conceptual construct, but rather refers to the utter truth that is objective in the universe alone, and everything else is subjective and depends on it.(Haq, 2008) Therefore, Tawhid suggests that in the whole world, there is only one Supreme God who is the Ultimate Lord and the Creator of all. $\mathrm{He}$ is One, in the sense that he is God.

He doesn't have a partner, and no equals, no rivals and no opponents. This implies that God is the source of all beauty, all goodness and power, of all values. Since he is the ultimate lord of everything, everything depends on him, since he is the Sole Creator of everything, and has given life and nature to it. Therefore, God is Almighty and Omnipotent, such that all things rest entirely on Him. The strict monotheistic environment of Islam is very typical of this absolute reliance of all things on God. Therefore, nothing is separate from God and outside His influence, or absent from Him. The entire created order is nothing in the face of God's utter truth. Al-Qur'an assents "Everything is perishing save His countenance" (28: 88). 
Furthermore, Tawhid means that God is with us, and wherever. This suggests that he is both transcendent and unavoidable, that the infinitely transcendent God is forever near at the same time, closer than your Jaguar vein, surrounding you and observing you. Al Qur'an announces this in an emphatic tone: "We are nearer to him than the Jaguiar vein". (50: 16). The Whole, the Infinite, the Eternal, from the Islamic point of view, is only God. Incomparable and the absolute Great that all greatness belongs to God alone, and therefore, there is no human grandeur in a general sense. Thus, Islam nullifies the concept of secular Humanism born from the Renaissance winch that has begun the phase of secular irreligion, immorality, cynicism and atheism ${ }^{1}$. Tawhid means, in the same way, that God is our immediate world since He contains all. Al-Qur'an alludes to His name al-Muhit, meaning one that contains anything. (4:126, of 41:54). God alone, therefore, preserves all and sustains it. Similarly, God is not only our immediate world but our ultimate world as well. The Qur'an also declares in an emphatic voice: "Thy Lord is the Uttermost End (53: 42); or again, "He is the First and the Last, the Outward and the Inward" (57: 3). Islam, thus, affirms that God is the ultimate end of everything.

Consequently, Tawhid means that everything has come from God and will return to Him eventually. This indicates that the Alfa is God and the Omega is He alone. This idea of the final returns to God or the eschatological truth makes a man fully aware of His origins and final being, as death is the doorway from this life into the hereafter Al-Qur'an talks of the incomprehensible sensation and pangs of death with a fiery eloquence, unforeseeable by comparison to any comparable phenomenon, that man cannot possibly recollect his history to bear witness to something of this nature. At death, man is met with the absolute dimension of ultimate reality: therefore, man refuses himself and it is the limbs of his body that will accuse him according to the Quran. (36:65). Projected into the absolute and deepest essence of things, man will become conscious of what he is in reality; he will ontologically organize himself and conclude that life was nothing except a moment, a play. (6:32, 79:45). Similarly, al-Qur'an refers to the terrible fear of the Day of Judgment when God correctly judges man's smallest action and it is followed eternal punishment in hell or eternal reward in haven. This is the keystone of all morality in Islam. Thus, the assurance of death, the post mortem experience with Heaven, the Judgment Day, and eternal reward and punishment - all these are so many of the Qur'an's great themes.

So, Tawhid does mean that God is the certain truth (cf. Al-Qur'an, 75:10) that no one can go outside of God's control, since there is no outside. A man cannot hide from God, since He is the True Self. Al-Qur'an says God is closer to man than he is to himself. (56:85). The ontological relation between God and man is overwhelming but inexplicable. Therefore; Al-Qur'an equates the forgetfulness of the remembrance of God with the forgetfulness of man's own self. (59: 19). This means that in fact everyone who forgets God forgets his or her own self. This is exactly what Christ said: 'Inside you is the Kingdom of God.' The truth of God is, therefore, inescapable and. It is irresistible his intimacy. In this sense, Al-Ghazali notes that when a man dies, his relationship with the world is forever gone, but his relationship with God is everlasting and, after death, will be much closer than ever.(Burckhardt, 1959)

So, it can be said in a nutshell, and God is the value of all ideals in Islam, the absolute measure of all, the root of all morals, and the supreme purpose of our lives. He is the root of all goodness and elegance and felicity. Our lives in this world would have been pointless, useless, and futile struggles, trouble, and life deprivations are tolerable and understandable only in terms of God's will and provision.

God in Islam is both knowable and unrecognizable. In his total Transcendence, the Divine Self is unknowable. But by His acts He is knowable, that is, through His creation and manifestation. Each phenomena of the universe, including man himself, is created and is therefore created by God, according to Al-Qur'an. His sign which is all acts as a sign or emblem bearing witness to his maker. A vast theme of the Qur'an is the symbolic essence of natural phenomena. Therefore, nature or natural phenomena do not have their ultimacy or final justification but are merely indications of their maker.(Burckhardt, 1959) Thus, with signs and signals referring to the unseen maker, the visible world is dispersed.

This verifies that behind the world of phenomena lies the world of phenomena, behind the created order, and then there resides the maker, the Lord of the universe. Therefore, the world of natural wonders is not selfinsufficient, possessing great causes or raison d'etre in itself. At present, these ideals of Islam are subjected to the challenges of the Modernism referred to above. While within the wider Muslim community (ummah) Muslims follow different religious practices ( i.e. Sunni and Shi'ite), they share in no small degree a similar textual language (i.e. Arabic) and similar religious beliefs based on the Al-Qur'an with their fundamental duties reflected in the five pillars of Islam: profession of faith, prayer, alms-giving, fasting, and pilgrimage.(Palmer, 2001) Traditional Muslims claim, as one of the leading interpreters of Islamic ideals for Western audiences: "Islam is essentially the religion of equilibrium and tolerance; suggesting a breadth of vision, global positions and fulfillment of human destiny in the universe".(Ahmed, 2004)

However, with criticism focused on arguments, simple in form but rather profound, Al Qur'an meets these challenges (in anticipation). Indeed, Islam has the answers to any conceivable human query in its centre. 


\section{Qur'anie Criticism of Modernism (in anticipation):}

Those who see only the sensible world of phenomena as the true truth, who deny the unknown world, referred to as 'Alam al-Ghaib' in Al-Quran, and who do not see in the phenomena the signs of the supreme Creator, are severely condemned by the Qur'an. They are blind, superficial, short-sighted, chasing for an illusion, taking a water mirage, according to the Qur'an (24: 39). Thus, the modern concept of 'secularism, Materialism, Naturalism and Atheism are strongly criticized by the holy Qur'an. These modems are quite aptly represented by Al-Qur'an: antireligious 'isms': "They know only the outward (materialistic) part of life and are heedless of the hereafter (Invisible side of life). Have they not looked deeply into their selves? For God, except for a reason and a definite word, has not created the heavens and the earth and everything between them, but most people do not know they will come face to face with their Lord .... then the end of those that did evil was evil for they cried out lies to the signs of God and mocked at that signs.". (30: 7-9). The upholders of modernistic worldview are, thus, condemned by Al-Qur'an as those who stick to the surface level of life and who desire only this earthly life, because it is the ultimate reach of their knowledge $(53: 29,30)$.

The supreme focus of Islam on the primacy and ultimacy of the truth of God and His absolute control over all His creation implies that unless it is connected back to its maker, the nature of the whole universe is uncertain. In the other hand, this theory emphatically points out the guilty silliness and absurdities of those pagan polytheists who allocate God to spouses and reject His Unity. By referring to the similarity of the web of spiders, which is the most flimsy and tenuous thing in the world, the Qur'an stigmatizes the actions of such people as most pointless and vain. Those who have accepted pseudo-gods or false 'isms' with whom they live are like those who have taken as their shelter the spider's web, and the weakest house is the spider's web. (29: 41).

Similarly, Islam criticizes company with the Atheists who reject the presence of God and claim that the world as a whole is a result of mere chance and blind evolutionary method. The same, it parts company with the Naturalists who deny After-life and hold that nature or natural process is self- sufficient and self-caused. The Qur'an expressly condemns their life-record as trivial and vain, although they judge it to be full of successes and exploits (18: 104. 105). Al-Qur'an mentions a parable rich with profound significance to highlight the absolute arrogance of their life-works. The whole life-work of the unbelievers is like a mirage that, a thirsty man desperately looking for water, mistakes for water, finds nothing until he gets closer to it, yet discovers God to his utter disillusionment, who is ever with him and God will pay him his account (24: 39). Now, like those deluded by mirage, the unbelievers find themselves: the reality they have denied is still with them: and the mirage they have embraced deceives them by being reduced to nothing. The Qur'an defines such persons as ignorant and inwardly blind, lacking proper insight into perception.

Every entity or item of existence serves as a sign of God, according to the Qur'an. Therefore, the universe is a panorama of facts, hints and signs pointing to God's infinite creative force. Yet natural phenomena do not constitute signs of God for the Atheists and Naturalists but are simply phenomena, a mushroom-product of unintended evolution. They are condemned by the Quran as dumb, deaf and stupid as animals, much worse than animals $(2: 171 ; 7: 179)$. It is mentionable that as divine signs, phenomena do not become arbitrary or unreal because they are not seen by many unbelievers, no more than the Sun becomes subjective or unreal because it cannot be seen by animals accustomed to darkness.(Rahman, 1980) For why, the great Persian Sufi poet Sa'di says: "if in a daytime, bat-eyed persons do not see, is it the fault of Sun, the fountain of light?"'

The Qur'an seems to question the protagonists of evolutionism with a taunting to ne: "Are they made out of nothing, or are they creators of their own" (52:35). The Qur'an advises people not to live in the world of speculation and conjecture, because man can neither attain the truth nor change the truth with mere conjecture and conjecture and conjecture. It is well known that Evolution's whole theory is largely founded on speculation. Yet the world of conjecture is still the realm of doubt and confusion. The conjecture-mongers are strongly criticized by the Qur'an: "They have no knowledge of that: they obey only conjecture and certainly conjecture uses nothing against truth" 53:28; 43:20; 6:116). Al-Qur'an also says:" These individuals follow their perceptions and what their minds want ... they want only the existence of this world, which is the absolute reach of their knowledge" $(53: 29.30)$. They are the slaves of their desires and have created a god of their desires; $(25: 43)$ such individuals are characterized by their worldliness, for example, their excessive love for worldly things. Al-Qur'an says: "But he gravitated down to the earth and followed his own desires" (7:76). They are also very likely to exist in the domain of conjecture, precisely because conjecture is compatible with their arbitrary desire and the world's affection. Thus, for Islam, harmony is essential and never more so than in society; and the crucial equilibrium is between din (religion) and dunya (worldly life); it is a harmony between the two, not a separation. A Muslim lives in a moment, in the real world, but within the context of his faith, aware of the paradise in the future. Thus, he must not neglect the spiritual laws of Islam, whether he is a businessman, a scholar or a politician. Dunya upsets the equilibrium in the postmodern world, invades and appropriates din.(Ahmed, 2004) 


\section{Conclusion}

The deadliest enemy of wisdom, as described above, is materialism or the materialist brand of modernism. Modernist worldview is deliberately vulnerable to the elimination of a higher level of truth or the elimination of God more specifically. It makes it possible to temporarily prosper by establishing an environment of profane secularism that removes God from all phases of life. Thus, by being cut off from the origins of all destining and wisdom, modernism has given birth to intellectual superficiality. Ecclesioning said: "The fear of God is the root of all wisdom".(Northbourne, 1983) Ecclesiastics said the same thing: "The fear of God is the beginning of all wisdom".(Northbourne, 1983) Therefore, Islam defines the fear of God as Taqwa (God consciousness), and Taqwa is a value as well as moral principle which guides accordingly that proportionately man has to avoid wrong and vicious deeds and has to be inclined towards good and virtuous deeds. But now practically the transcendent root of all knowledge and wisdom is forgotten. The universe becomes a Ji circle without a middle, once the Transcendent Source or Concept of all things is removed, which is a contradiction in terms and a great paradox on the uncertainty of which the entire theory of Modernism stands.

Evolutionism is, likewise, the deadliest foe of religion. It is the most insidious of all Modernism's pseudodogmas, for it attacks al the centre of faith and slices the whole cloth inwardly. No scientific hypothesis has become as damaging to religious belief and toxic as the theory of evolution.(Nasr, 1983) This suggests that everything in the world has automatically come into existence out of a chance event without the idea of creation existence concerned with intent in any way. Therefore, it is a mechanism which is blind and aimless. The theory of existence and rejection of existence is thus rejected by evolution, which logically amounts to the rejection of the Creator, that is, of God as the absolute Lord of the universe When God is rejected and removed, like a house of cards, the whole fabric of faith is hounded to collapse.

Except God, without the topic of revelation, prophecy, morality, eschatology, judgment, immorality, all these elements of belief are irrelevant, useless and ambiguous. The topic of religious tradition makes no sense when religion is ignored. Yet the inalienable and irreplaceable legacies of society, in general, are faith and religious culture.

The great religions are widely believed to be the roots and matrices that have given rise to the great civilizations of the world. Hence, all human values such as faith, religious practice, culture, intelligence, history, seem valueless, unintended and paradoxical for evolutionism, precisely because modern man is nothing more than an ape, pure and simple, having developed from almost nothing and becoming a fungal result of unintended evolution. For those who have eyes to see and hearts to understand, these are the most pernicious consequences of evolutionism on religious beliefs that are manifestly obvious. The most inconceivable absurdity that the world has ever learnt is evolutionism, and that is why the belief of it is the most inconceivable mental aberration imaginable. According to F. Schuon, "if the evolutionists arc right, the human phenomenon is inexplicable and human life is not worth living".(F. Schuon, 1982)

Instead of the religious doctrine of Divine conception, the upholders of Modernism from heart evolutionism, precisely because it corresponds to their profane and world-oriented irreligious outlook. In theory amoral, but it fulfils their unethical philosophy of Hedonism. Evolutionism makes it easier for them, without pricks of guiltconsciousness or without confronting the awful prospect of standing before God on the Day of Judgment, to become the slave of their carnal lust and to lead a life of concupiscence.

In reality, it gives them full freedom to lead their lives as they wish and thus to make their arbitrary desire a successful one. This human pattern is referred to by Al-Qur'an: "Hast thou seen him who has taken hit arbitrary desire to be his god" (25: 43) But the life of this planet is not, as modern man has taken for granted, an end in itself. Through its fleeting pleasantness or by its ephemeral satisfaction and performance, it is not and cannot be justified. Death, which is ever staring one in the face, is the only assurance in life; it is the unavoidable moment of existence.

We cannot get our past back, nor can we perpetuate our present joy, nor can we avoid our imminent confrontation with death, we are attracted by an overwhelming force through life and death. To this new age, the profound importance of these facets of life and death seems to be forgotten. They believe that, beyond the short span of the earthly profession, human life is purposeless and has no future; it is doomed to nothingness after death. But religion's perennial message is that death is not the end of life; instead, it is the key to everlasting life, good or bad, life is full of reason, sense and value, the highest of which is the encounter with God Himself-a meeting in a human language whose real nature and style are indescribable.

Therefore, today's internal and external threats challenge the very existence of religion. Internally, religion is falsified, reformed and corrupted to make it modem to make it relevant to the era of the modem, an erroneous method of accommodating falsehood to the truth. Modem dogmas and 'isms' arc externally seeking to elbow religion out of existence by strangulating it with multi-pronged assaults. Given this ominous sign and crisis, the revival of religious awareness and practice in all forms and all facets of life should be given top priority. Antireligious knowledge and imitation teachings, on the other hand, should be systematically checked by all possible means. This is the only exact way to express our heritage and save humanity from the incubus of utter extinction to the young and all subsequent generations. The modernist science brand is the direct result of modernism; it is 
atheistic in attitude since the spirit of atheism is the foundation of modernism.(F. Schuon, 1961) Modem science is not wisdom; it is merely a set of practical know-how that lacks any Divine orientation. That is why an atom bomb and similar lethal weapons could be made. A Gospel statement seems to be quite fitting in this sense. "all they that take the sword shall perish with the sword." The barest and deadliest sword drawn by modern man is the atom bomb here, and he is most likely to perish with it, precisely because the scriptures never utter a lie. But what is both most disappointing and intolerably painful is that innocent men are also liable to perish with him. In fact, it is not only humanity that can be wiped out of existence, but may also be the whole universe. Here, only Islam makes out that knowledge which is actually useful and beneficial to mankind and which helps man to acquire values beyond all other modern religion and cultural values. Thus the holy Prophet of Islam Muhammad (Peace be upon him) prayed to Almighty Allah: "O Lord! We seek refuse from the knowledge which carries no utility."3

\section{References}

Ahmed, A. S. (2004). Postmodernism and Islam: Predicament and promise: Psychology Press.

Al-ghazali, A. H. M. I. (1358/1937). Ihya' 'Ulum al-Din (Vol. 01). Cairo, Egypt: Matba'at Boulaq, Cairo.

Burckhardt, T. (1959). An Introduction to Sufi Doctrine (D. M. Matheson, Trans.). Lahore. Pakistan: Ashraf Publications.

Haq, M. A. (2008). Islamic Values and the Challenges of Modernism. In A. F. N. A. Khan (Ed.), 21st Century Challenges for the Global Muslim Community Knowledge, Development and Revival: Selected Oriental Perspectives (pp. 195). Dhaka, Bangladesh: Renaissance Foundation for Human Resource Management (RFHRM).

Moten, A. R. (2011). Modernity, tradition and modernity in tradition in Muslim societies. Intellectual Discourse, $19(1)$.

Nasr, S. H. (1979). Intellect and Intuition: Their Relationship from the Islamic Perspective. Studies In Comparative Religion, Vol. 13, No. 1 \& 2(Winter-Spring, 1979), 1-09.

Nasr, S. H. (1983). Reflections on Islam and Modern Thought. Studies In Comparative Religion, The First English Journal on Traditional Studies - established 1963, Vol. 15, No. 3 \& 4 (Summer-Autumn, 1983), 1-13.

Northbourne, L. (1963). Religion in the Modern World. London, UK: J.M. Dent \& Sons.

Northbourne, L. (1983). Religion and Science. Studies In Comparative Religion

The First English Journal on Traditional Studies - established 1963, Volume 15, Number 3 and 4(Number 3 and 4), 1-13.

Palmer, A. W. (2001). and Western Culture. Bridges, 2.

Rahman, F. (1980). Major Themes of the Quran, Bibliotica Islamica. Chicago: Minneapolis.

Ramadan, T. (2001). Islam, the West and the Challenges of Modernity (S. Amghar, Trans.). Markfield Conference Centre, Ratby Lane,

Markfield, Leicester LE67 9SY, UK: The Islamic Foundation.

Schuon, F. (1961). Stations of Wisdom: J. Murray.

Schuon, F. (1982). From the Divine to the Human: Survey of Metaphysics and Epistemology: World Wisdom Books.

Schuon, F. (1984). The Transcendent Unity of Religions (Second Quest edition 1993 ed.). Wheaton, Illinois + Chennai (Madras), India Quest Books, Theosophical Publishing House

\section{Notes}

Note 1: Dictionary of the History of Ideas, Vol. II. Charles Scribner's Sons, New York. 1973. P.520.

Note 2: Sa'di, Shirazi, The Gulistan, Trans. By Richard Francis Burton, p. 24

Available at file://G:/MY\%20Library/Gulistan\%20Sheikh\%20Saadi.pdf

Note 3: Al- Hadith, Ibn Majah (Sunan, under no. 250). 